\title{
A preliminary report of relationship between abortion and $Q$ fever in Central Black Sea Region Turkish woman
}

\author{
Orta Karadeniz, Bölgesi kadınlarında abortus ve $Q$ ateşi arasındaki ilişkinin \\ incelenmesi
}

\author{
Özgür Günal*, Fazlı Demirturk, Şener Barut, Selçuk Kılıç, Ünal Erkorkmaz, Feyza \\ Yıldız Aytekin, Tülay Aysal
}

Department of Infectious Diseases and Clinical Microbiology (Assoc. Prof. Ö. Günal, MD, Assoc. Prof. Ö. Barut, MD, F. Y. Aytekin, MD), Department of Obstetrics and Gynecology (Prof. Dr. F. Demirtürk, MD, T. Aysal, MD), Gaziosmanpaşa University School of Medicine, 60100 Tokat, Zoonotic Diseases Section (Assoc. Prof. S. Kilıç, MD), Republic of Turkey Ministry of Health, Health Agency of Turkey, 06100 Ankara, Department of Medical Statistics (Assist. Prof. Ü. Erkorkmaz, MD), Sakarya University School of Medicine, TR-54290 Sakarya

\begin{abstract}
Aim. Q fever, which is a zoonosis caused by Coxiella burnetii, may result in abortions in infected animals and pregnant women. In our study, we searched the association between $\mathrm{Q}$ fever serology and abortion in a region where $\mathrm{Q}$ fever is endemic. Method. This study was conducted in Gaziosmanpaşa University Hospital between March and May 2012. A total of 100 women, from these, 64 had a history of spontaneus abortion (cases) and 36 had live births with no complicated obstetrics history or complicated partum (controls), enrolled in the study. Both groups were compared according to where they live, underlying diseases, contact with farm animals or pets and village connectivity. Results. IgG seroprevalence of Coxiella in our study group with the history of abortion was $15.6 \%$, and $11.1 \%$ in the control group ( $p>0.05)$. When case and control groups were compared, the frequency of inhabitants of the village $(\mathrm{p}=0.012)$, subjects who had contact with farm animals $[p=0.026$, especially cattle $(p=0.013)]$ or domestic animals $(p=0.018)$ in case group were more common than the control group. When all the samples were analyzed, it was seen that the only significant variable affecting Coxiella IgG seropositivity was residency in rural area or visiting rural area $(\mathrm{p}=0.018)$. Conclusions. We have found that the relation between abortion and Q fever infection was not statistically significant. On this issue, multicenter studies which have the higher number of samples are needed in our country.
\end{abstract}

Keywords: Q fever, spontaneous abortions, endemic region

\section{Özet}

Amaç. Q ateşi Coxiella burnetii tarafindan oluşturulan bir zoonozdur. Q ateşi gebe hayvanlarda ve gebe kadınlarda abortusa neden olabilir. Biz bu çalışmamızda Q ateşi için endemik bir bölgede Q ateşi seropozitifliği ve abortus arasındaki ilişkiyi araştırdık. Yöntem. Bu çalışma Gaziosmanpaşa Üniversitesi Hastanesinde Mart 2012-Mayıs 2012 tarihleri arasında yürütüldü. Çalışmaya 18 yaş üzerinde toplam $100 \mathrm{kadın}$ dahil edildi. Bunların 64'ünün spontan abortus hikayesi pozitif (vaka grubu) iken 36'sının hiç komplikasyonlu gebelik veya doğum hikayesi yoktu (kontrol grubu). Her iki grup yaşadıkları yer, altta yatan hastalıkları, çiflik hayvanı veya evcil hayvanlarla temas ve köy yaşantısı ile ilişki açısından karşılaştırıldı. Bulgular. Vaka grubunda Coxiella lgG seropozitifliği $\% 15,6$ çıkarken kontrol grubunda \%11,1 olarak saptand1, bu fark istatistiksel olarak anlamlı değildi ( $p>0,05)$. Vaka grubu kontrol grubuyla karşılaştırıldığında köyde yaşama $(p=0,012)$, çiftlik hayvanları ile temas $[\mathrm{p}=0,026$; özellikle koyun $(\mathrm{p}=0,013)]$ veya evcil hayvanlarla temas $(\mathrm{p}=0,018)$ vaka grubunda anlamlı derecede daha yüksek saptandı. Tüm örnekler analiz edildiğinde Coxiella IgG seropozitifliğini etkileyen en önemli değişken kırsal alanda yaşama veya kırsal yaşamla ilişsili olma olarak bulundu ( $\mathrm{p}=0,018$ ). Sonuç. Çalışmanın sonucunda $\mathrm{Q}$ ateşi ile abortus arasında anlamlı bir ilişki bulunamadı. Bu çalışma bu konuyla ilgili ülkemizde yapılmış ilk çalışma olmakla birlikte çok merkezli ve yüksek örneklem sayılı çalışmalara ihtiyaç vardır.

Anahtar sözcükler: Q ateşi, spontan abortus, endemik hastalık 
Geliş tarihi/Received: April 03, 2014; Kabul tarihi/Accepted: August 08, 2014

\section{*Corresponding author:}

Dr. Özgür Günal, Samsun Eğitim Araştırma Hastanesi Enfeksiyon Hastalıkları ve Klinik Mikrobiyoloji Kliniği, TR-55100 Samsun. E-mail: ozgurgop@yahoo.com

\section{Introduction}

Q fever is a zoonosis created by Coxiella burnetii and seen all around the world [1]. The primary reservoirs of the bacterium are farm animals such as cattle, goats and sheep, but it may also be found in other domestic mammals (cat, dog, rabbit), birds and ticks. Bacteria is excreted in the urine, feces and milk of infected animals but the highest concen-trations are present in their birth products [2].

It has been reported that humans are infected through inhalation of contaminated aerosols. In addition C. burnetii can be transmitted by oral intake of infected milk. While human to human transmission is rare, the transmission can be from the infected mother to baby [3].

Q fever diagnosis remains to be based upon serological methods because culture and molecular biology techniques have low sensitivity and are available only in reference laboratories. The techniques most commonly used include complement fixation, IFA, ELISA, and microagglutination. The IFA remains the reference technique for $\mathrm{Q}$ fever diagnosis [2]. The IFA detects IgM and IgG antibodies against phase II (acute infection) and phase I (chronic infection) antigens of $\mathrm{C}$. burnetii. The negative/positive cut-off point differs between areas depending on the level of exposure of the specific population and it is always determined by seroprevalence studies [3].

In humans, $\mathrm{Q}$ fever has an acute and chronic form. Acute $\mathrm{Q}$ fever usually presents as a self-limited febrile illness with flu-like symptoms, but severe infections such as pneumonia, hepatitis and central nervous system infection can also occur. The most common chronic form is endocarditis, mainly in patients with underlying valvulopathies $[2,4]$. Clinical characteristics of $\mathbf{Q}$ fever infection in pregnant and nonpregnant patients are samely [5].

C. burnetii infection may be asymptomatic, but, may impact both the mother and fetus. Acute $\mathrm{Q}$ fever may reactivate during pregnancy or may progress to chronicity, causing recurrent episodes of premature birth. The risk of developing chronic $\mathrm{Q}$ fever after acute infection is much higher in pregnant women than in the general population [6].

Women with a history of adverse pregnancy outcomes (intrauterine growth retardation, abortions and oligoamnios) should also be tested for Q fever [7]. Nevertheless, the role that $\mathrm{Q}$ fever plays in spontaneous abortions is still unknown [8].

Due to the rare literature on $\mathrm{Q}$ fever in pregnancy, the risks of adverse pregnancy outcome among infected women remain largely unknown, and even though $\mathrm{Q}$ fever is endemic worldwide many obstetricians know little about the infection. The incidence of $\mathrm{Q}$ fever among pregnant women may therefore be underestimated [9].

The aim of the present study was to evaluate the relationship between Q fever serology and spontaneous abortions among women in a our region where $\mathrm{Q}$ fever is endemic. 


\section{Material and method}

Study was conducted in Gaziosmanpaşa University, School of Medicine between March and May 2012. A total of 100 women, from these, 64 had history of spontaneus abortion (cases) and 36 had live births with no history of previous complicated obstetrics or complicated partum (controls) were included in the study. Both the control women and those with abortions were patients who attended gynecolgy and obstetrics and infection diseases clinics consequtively. Selection was done according to the history of the patient. Those with two or more abortions were selected as the study group. The patients with no abortions were included in the control group. The epidemiological and clinical data were obtained using a personalized questionnaire before the serology test results were available.

The cases had abortions in a time period differing from one years to three years. Spontaneous abortion is defined as any pregnancy that is not viable (the fetus cannot survive) or in which the fetus is born before the 20th week of pregnancy.

Both groups were compared according to where they live (urban area or rural ares), underlying diseases, contact with farm animals or pets and village connectivity (often commute to the rural area). We considered rural area term as a geographic area that is located outside the cities and towns, and urban area as city or town. Blood samples were collected by vene puncture, and serum samples were stored at $-80{ }^{\circ} \mathrm{C}$ until analysis.

The presence of IgM and IgG antibodies to C.burnetii phase II was investigated using a commercially avaliable IFA (Vircell SL ${ }^{\circledR}$ Granada, Spain). The assays were conducted according to the manufacturer's instructions. Samples with IgG titer of 1: 64, $1 \mathrm{gM}$ titer of 1: 24 were considered positive according to previous seroprevalence studies; 3.10 Positive and negative controls were run with each test.

\section{Statistical analysis}

Kolmogorov-Smirnov test was used to evaluate whether the distribution of continuous data were normal. Therefore, two independent sample t test was used to compare the continuous variables between groups. The continuous variables were presented as the mean \pm standard deviation. Chi-Square test was used to compare the categorical variables between groups. Categorical variables were presented as a count and percentage. A pvalue $<0.05$ was considered significant. Analyses were performed using commercial software (IBM SPSS Statistics 19, SPSS inc., an IBM Co., Somers, NY).

\section{Results}

A total of 100 samples were tested. Patient characteristics and serological results are summarized in Table 1. While IgG seroprevalence of Coxiella in our study group with the history of abortion was $15.6 \%$, in the control group, it was detected as $11.1 \%$. This difference was not statistically significant.

When the case and control groups were compared, the frequency of inhabitants of the village ( $\mathrm{p}=0.012$ ), subjects who had contact with farm animals $[\mathrm{p}=0.026$, especially cattle $(\mathrm{p}=0.013)]$ or domestic animals $(\mathrm{p}=0.018)$ in case group were more common than the control group and these differences were statistically significant. Again, rural area connectivity in the case group was significantly higher than the control group $(\mathrm{p}=0.006)$. When all the samples were analyzed, it was seen that the only significant variable affecting IgG Coxiella seropositivity was the rural area connection ( $\mathrm{p}=0.018)$ (Table 2). Also it was not determined a relation between Coxiella IgG seropositivity and the number of abortions

Acute $\mathrm{Q}$ fever positivity was detected in a total of 5 patients. Four of these were control cases and one was study case. They were asyptomatic patients. 
Table 1. Demographic and individual characteristics of study groups.

\begin{tabular}{|c|c|c|c|c|}
\hline & & Abortion $(n=64)$ & Control $(n=36)$ & $\mathbf{p}$ \\
\hline Age & & $26.41 \pm 5.77$ & $28.25 \pm 5.27$ & 0.117 \\
\hline Abortion number & & $1.52 \pm 0.78$ & - & - \\
\hline \multirow{2}{*}{ Residence } & Urban area & $43(67.2)$ & $33(91.7)$ & \multirow{2}{*}{0.012} \\
\hline & Rural area & $21(32.8)$ & $3(8.3)$ & \\
\hline \multirow{2}{*}{ Contact with animals } & None & $45(70.3)$ & $33(91.7)$ & \multirow{2}{*}{0.026} \\
\hline & Available & $19(29.7)$ & $3(8.3)$ & \\
\hline \multirow{2}{*}{ Animal contact } & Cattle & $16(84.2)$ & 0 & \multirow{2}{*}{0.013} \\
\hline & Cattle + sheep & $3(15.8)$ & $3(100.0)$ & \\
\hline \multirow{2}{*}{ Contact with domestic animals } & None & $44(68.8)$ & $33(91.7)$ & \multirow{2}{*}{0.018} \\
\hline & Available & $20(31.3)$ & $3(8.3)$ & \\
\hline \multirow{4}{*}{ Contact with domestic animal species } & Cat & $11(55.0)$ & $3(100.0)$ & \multirow{4}{*}{0.528} \\
\hline & Dog & $2(10.0)$ & & \\
\hline & Bird & $3(15.0)$ & & \\
\hline & Cat+Dog & $4(20.0)$ & & \\
\hline \multirow{2}{*}{ Pregnancy } & None & $44(68.8)$ & $28(77.8)$ & \multirow{2}{*}{0.463} \\
\hline & Available & $20(31.3)$ & $8(22.2)$ & \\
\hline \multirow{2}{*}{ Phase II IGM } & Negative & $63(98.4)$ & $32(88.9)$ & \multirow{2}{*}{0.055} \\
\hline & Positive & $1(1.6)$ & $4(11.1)$ & \\
\hline \multirow{2}{*}{ Phase II IG G } & Negative & $54(84.4)$ & $32(88.9)$ & \multirow{2}{*}{0.746} \\
\hline & Positive & $10(15.6)$ & $4(11.1)$ & \\
\hline \multirow{2}{*}{ Rural area connection } & None & $23(35.9)$ & $24(66.7)$ & \multirow[t]{2}{*}{0.006} \\
\hline & Available & $41(64.1)$ & $12(33.3)$ & \\
\hline
\end{tabular}

Data were presented as $\mathrm{n}(\%)$ and mean \pm standard deviation

Table 2. Demographic and individual characteristics of seronegative and seropositive groups.

\begin{tabular}{|c|c|c|c|c|}
\hline & & $\operatorname{IgG}(-),(n=86)$ & IgG (+), $(n=14)$ & $\mathbf{p}$ \\
\hline Age & & $27.02 \pm 5.67$ & $27.36 \pm 5.61$ & 0.838 \\
\hline Abortion number & & $1.57 \pm 0.82$ & $1.20 \pm 0.422$ & 0.041 \\
\hline \multirow{2}{*}{ Residence } & Urban area & $66(76.7)$ & $10(71.4)$ & \multirow{2}{*}{0.738} \\
\hline & Rural area & $20(23.3)$ & $4(28.6)$ & \\
\hline \multirow{2}{*}{ Contact with farm animals } & None & $66(79.1)$ & $10(71.4)$ & \multirow{2}{*}{0.502} \\
\hline & Available & $18(20.9)$ & $4(28.6)$ & \\
\hline \multirow{2}{*}{ Contact with animal species } & Cattle & $14(77.8)$ & $2(50.0)$ & \multirow{2}{*}{0.292} \\
\hline & Cattle+sheep & $4(22.2)$ & $2(50.0)$ & \\
\hline \multirow{2}{*}{ Contact with domestic animals } & None & $66(76.7)$ & $11(78.6)$ & \multirow{2}{*}{1.000} \\
\hline & Available & $20(23.3)$ & $3(21.4)$ & \\
\hline \multirow{4}{*}{ Contact with domestic animal species } & Cat & $12(60.0)$ & $2(66.7)$ & \multirow{4}{*}{0.736} \\
\hline & Dog & $2(10.0)$ & 0 & \\
\hline & Bird & $3(15.0)$ & 0 & \\
\hline & Cat+ Dog & $3(15.0)$ & $1(33.3)$ & \\
\hline \multirow{2}{*}{ Pregnancy } & Not pregnant* & $66(76.6)$ & $11(78.6)$ & \multirow{2}{*}{0.752} \\
\hline & Pregnant** & $20(23.2)$ & $3(21.4)$ & \\
\hline \multirow{2}{*}{ Phase II LGM } & Negative & $86(100.0)$ & $9(64.3)$ & \multirow{2}{*}{$<0.001$} \\
\hline & Positive & 0 & $5(35.7)$ & \\
\hline \multirow{2}{*}{ Abortion } & None & $45(62.8)$ & $2(71.4)$ & \multirow{2}{*}{0.746} \\
\hline & Available & $41(37.2)$ & $12(28.6)$ & \\
\hline \multirow{2}{*}{ Rural area connection } & None & $54(52.3)$ & $10(14.3)$ & \multirow{2}{*}{0.018} \\
\hline & Available & $32(47.7)$ & $4(85.7)$ & \\
\hline
\end{tabular}

Data were presented as n (\%) and mean \pm standard deviation. *: Women who were pregnant at the blood sampling time. $* *$ :Women who were not pregnant at the blood sampling time

\section{Discussion}

In Turkey, since the 1940s, cases of Q fever in humans and animals have been reported and until 1951, Q fever cases were identified in 20 provinces [11, 12].

In a study conducted among blood donors in our country Coxiella IgG seropositivity rate was detected as $32.2 \%$ [10]. Gözalan and colleagues in their study of the western Black Sea Region, they detected Coxiella seropositivity in the $13.5 \%$ of the 407 samples [13]. Berberoğlu et al. [14] were found IgG seroprevalence of Coxiella as $7.1 \%$ in their study of 339 healthy subjects held in Samsun, Diyarbakir and Antalya provinces. 
The people in Tokat Province (Middle Black Sea Region of Turkey) are at risk for zoonotic diseases, because cities are very close to the rural area and people have been coming and going frequently to the villages. In this study, in general, Coxiella IgG seropositivity was found as $14 \%$. This rate is similar to other studies conducted in Samsun (Also in Middle Black Sea Region of Turkey), but higher than Diyarbakır and Antalya.

Q fever may be asymptomatic, or may impact both the mother and fetus. Acute Q fever may reactivate during pregnancy or may progress to chronicity, causing recurrent episodes of premature birth. Obstetric complications of $\mathrm{Q}$ fever are known as prematurity, intrauterine growth retardation, low birthweight, oligoamnios, intrauterine fetal death or spontaneous abortion [3].

Q fever was $25.7 \%$ in women with a history of adverse pregnancy outcomes, signifying the importance of $\mathrm{Q}$ fever as a major cause of obstetric complications [15].

Baud et al. [16] found that 20 out of 438 women $(4.6 \%, 95 \%$ CI 2.8-7.1) had positive phase II IgG antibodies for C. burnetii. None was positive for C. burnetii phase I IgG antibodies. Only two $(0.5 \%, 95 \%$ CI $0.1-1.7)$ also exhibited IgM antibodies against C. burnetii. No statistical differences were observed between $C$. burnetii $\operatorname{IgG}$ seroprevalences in women with sporadic $(1 / 69 ; 1.4 \%$; $95 \%$ CI $0.1-8.1 ; \mathrm{p} 0.188)$ or recurrent miscarriage $(8 / 200,4 \%, 95 \%$ CI $1.7-7.9 \%$; p 0.346) compared to controls $(11 / 169 ; 6.5 \%, 95 \%$ CI 3.2-11.6).

In a study conducted on 500 pregnant women, Quijada et al. [8], found seropositivity as $32.2 \%$ in the 273 women with a history of spontaneous abortion, while in the control group it was found as $23.3 \%(\mathrm{p}<0.01)$. As a result of this study, it was concluded that active or the recent $\mathrm{Q}$ fever infection is associated with the risk of abortion. Authors also suggested that serological monitoring of $\mathrm{Q}$ fever in pregnant women from endemic areas was needed.

Evidence of $\mathrm{C}$. burnetii as a cause of abortion in humans is scarcer; only 23 cases (including those we described) have been reported. In five of these cases, pregnancy was followed by the birth of a healthy child; in eight, the child was born prematurely; in eight the fetus aborted; and in two, the neonate died [17].

In our study while $\operatorname{IgG}$ seroprevalence of Coxiella was found as $15.6 \%$ in the group with a history of abortion, in the control group, it was $11.1 \%$. This difference was not statistically significant. The current study is the first study investigating the relationship between the risk of abortion and Q fever seropositivity in our country. Similarly, in a study from Denmark, Nielsen et al. [18], found no evidence of a higher prevalence of C.burnetii antibodies in serum samples from women who later miscarried and their study did not indicate a major association between $\mathrm{Q}$ fever infection and spontaneous abortion in humans.

van der Hoek et al. [19] in their study, examined serum samples from 1174 pregnancies with a gestational age of 16 weeks or more from women living in the high-risk area and found no association between positive $\mathrm{Q}$ fever serology and adverse pregnancy outcome.

In our study, in a total of 5 patients, acute Q fever positivity was detected. Four of these were control cases and one was study case. We can not explain this, but studies with higher case numbers can show more clear results. However, none of them were pregnant. Fourteen women, who were positive for $\mathrm{Q}$ fever serology, were followed and were informed about the need for close monitoring if become pregnant in the successive periods.

Treatment of Q fever in pregnancy is difficult as first-line antibiotics (doxycycline, hydroxychloroquine and fluoroquinolones) are contraindicated and cotrimoxazole remains the only effective antibiotic. Administration of cotrimoxazole probably prevents 
abortion but not the development of chronic infections or placental colonization [20]. In a recent series, administration of long-term cotrimoxazole ( $>5$ weeks) significantly decreased the occurrence of serious fetal complications compared with patients who did not receive co-trimoxazole [6].

It has been revealed that occupational risks of $\mathrm{Q}$ fever are higher in some groups such as farm-ers, abattoir workers, wool or hides, veterinarians and other professionals who manage ani-mals, especially when they give birth, and laboratory personnel who come in contact either with human products containing C. burnetii or with infected animals [3].

In our study, the number of people living in the rural area, again the contact with farm animals (especially cattle) and domestic animals were more in the case group than the other group, and these differences were statistically significant. However, connection to the rural area in the seropositive group was significantly higher than the seronegative group. In our study, the most important risk factor for Coxiella IgG positivity was detected as the commuting lifestyle of the people to the rural area. Coxiella IgG positivity was found a much lower rate in the people living in urban areas or in those without a history of the rural area commute. These results are consistent with the risk factors of $Q$ fever.

Kilic et al. [10], in their study did not found a relation between coming into contact with pets or a history of contact with the farm animals and Coxiella IgG seropositivity.

Weaknesses of the study; to clear whether there is a relation between $\mathrm{Q}$ fever and abortion exactly, multicenter studies which have the higher number of samples are needed in our country. Tokat province which is in the Middle Black Sea Region of Turkey is an area which have short distances and much interaction between rural and urban areas.

In conclusion; our study is the first study done in Turkey to show the relationship between Q fever and the risk of abortion. Compared to the control group, in the cases with the history of abortion, seropositivity of Q fever was found on higher rate but this difference was not statistically significant. Also living in the rural area and having rural area connection increases the risk of seropositivity. To clear whether there is a relation between $\mathrm{Q}$ fever and abortion exactly, multicenter studies which have the higher number of samples are needed in our country.

\section{References}

1. Madariaga MG, Rezai K, Trenholme GM, Weinstein RA. Q fever: A biological weapon in your backyard. Lancet Infect Dis 2000; 3: 709-21.

2. Maurin M. Raoult Q fever. Clin. Microbiol Rev 1999; 12: 518-3.

3. Gikas A, Kokkini S, Tsioutis C. Q fever: Clinical manifestations and treatment. Expert Rev Anti Infect Ther 2010; 8: 529-39.

4. Rey D, Obadia Y, Tissot-Dupont H, Raoult D. Seroprevalence of antibodies to Coxiella burnetti among pregnant women in South Eastern France. Eur J Obstet Gynecol Reprod Biol 2000; 93: 151-6.

5. Syrucek L, Sobeslavsky O, Gutvirth I. Isolation of Coxiella burnetii from human placentas. J Hyg Epidemiol Microbiol Immunol 1958; 2: 29-35.

6. Carcopino X, Raoult D, Bretelle F, Boubli L, Stein A. Managing Q fever during pregnancy: The benefits of long-term cotrimoxazole therapy. Clin Infect Dis 2007; 45: 548-55.

7. Carcopino X, Raoult D, Bretelle F, Boubli L, Stein A. Q fever during pregnancy: A cause of poor fetal and maternal outcome. Ann NY Acad Sci 2009; 1166: 7989.

8. Quijada SG, Terán BM, Murias PS, Anitua AA, Cermeño JL, Frías AB. Q fever and spontaneous abortion. Clin Microbiol Infect 2012; 18: 533-8.

9. Tissot-Dupont H, Vaillant V, Rey S, Raoult D. Role of sex, age, previous valve lesion, and pregnancy in the clinical expression and outcome of $\mathrm{Q}$ fever after a 
large outbreak. Clin Infect Dis 2007; 44: 232-7.

10. Kilic S, Yilmaz GR, Komiya T, Kurtoglu Y, Karakoc EA. Prevalence of Coxiella burnetii antibodies in blood donors in Ankara, Central Anatolia, Turkey New Microbiol 2008; 31; 527-34.

11. Payzın S. Epidemiological investigations on Q fever in Turkey. Bull World Health Organ 1953; 9: 553-8.

12. Golem SB. La Q flevre en Turquie: l'epidemiologie et une revue sommaire sur la flevre $\mathrm{Q}$ des animaux $(\mathrm{Q}$ feverepidemiology and information on $\mathrm{Q}$ fever infection among animals in Turkey).Turkish Bull Hyg Exp Biol 1951; 11: 1-21.

13. Gozalan A, Rolain JM, Ertek M, EAngelakis E, Coplu N, Basbulut EA, Korhasan BB, Esen B. Seroprevalence of Q fever in a district located in the west Black Sea Region of Turkey. Eur J Clin Microbiol Infect Dis 2010; 29: 465-9.

14. Berberoğlu A, Gözalan S, Kılıç S, Kurtoğlu D, Esen B. A Seroprevalance of Coxiella Burnetii in Antalya, Diyarbakır and Samsun Provinces. Microbiol Bul 2004; 38: 385-91.

15. Vaidya VM, Malik SV, Kaur S, Kumar S, Barbuddhe SB. Comparison of PCR, immunofluorescence assay, and pathogen isolation for diagnosis of $\mathrm{Q}$ fever in humans with spontaneous abortions. J Clin Microbiol 2008; 46: 2038-44.

16. Baud D, Peter O, Langel C, Regan L, Greub G. Seroprevalence of Coxiella burnetii and Brucella abortus among pregnant women. Clin Microbiol Infect 2009; 15: 499-501.

17. Stein A, Raoult D. Q fever during pregnancy: A Public Health Problem in Southern France Clinical Infectious Diseases 1998; 27: 592-6.

18. Nielsen SY, Hjøllund NH, Andersen AM, Henriksen TB, Kantsø B, Krogfelt KA. Presence of antibodies against Coxiella burnetii and risk of spontaneous abortion: a nested case-control study. PLoS One 2012; 7: 31909.

19. Van der Hoek W, Meekelenkamp JC, Leenders AC, Wijers N, Notermans DW, Hukkelhoven CW. Antibodies against coxiella burnetii and pregnancy outcome during the 2007-2008 Q fever outbreaks in the Nedherlands. BMC Infect Dis 2011; 11: 44.

20. Raoult D, Fenollar F, Stein A. Q fever during pregnancy: Diagnosis, treatment, and follow-up. Arch Intern Med 2002; 162: 701-4. 